\title{
Receptive Field Properties of Color Opponent Neurons in the Cat Lateral Geniculate Nucleus
}

\author{
Péter Buzás, ${ }^{1}$ Péter Kóbor, ${ }^{1}$ Zoltán Petykó, ${ }^{1}$ Ildikó Telkes, ${ }^{1}$ Paul R. Martin, ${ }^{2,3}$ and László Lénárd ${ }^{1}$ \\ ${ }^{1}$ Institute of Physiology, Medical School, University of Pécs, 7624 Pécs, Hungary, and ${ }^{2}$ Save Sight Institute and School of Medical Sciences and ${ }^{3}$ Australian \\ Research Council Centre of Excellence in Vision Science, University of Sydney, Sydney, New South Wales 2001, Australia
}

\begin{abstract}
Most nonprimate mammals possess dichromatic ("red-green color blind") color vision based on short-wavelength-sensitive (S) and medium/long-wavelength-sensitive (ML) cone photoreceptor classes. However, the neural pathways carrying signals underlying the primitive "blue-yellow" axis of color vision in nonprimate mammals are largely unexplored. Here, we have characterized a population of color opponent (blue-ON) cells in recordings from the dorsal lateral geniculate nucleus of anesthetized cats. We found five points of similarity to previous descriptions of primate blue-ON cells. First, cat blue-ON cells receive ON-type excitation from S-cones, and OFF-type excitation from ML-cones. We found no blue-OFF cells. Second, the S- and ML-cone-driven receptive field regions of cat blue-ON cells are closely matched in size, consistent with specialization for detecting color contrast. Third, the receptive field center diameter of cat blue-ON cells is approximately three times larger than the center diameter of non-color opponent receptive fields at any eccentricity. Fourth, S- and ML-cones contribute weak surround inhibition to cat blue-ON cells. These data show that blue-ON receptive fields in cats are functionally very similar to blue-ON type receptive fields previously described in macaque and marmoset monkeys. Finally, cat blue-ON cells are found in the same layers as W-cells, which are thought to be homologous to the primate koniocellular system. Based on these data, we suggest that cat blue-ON cells are part of a "blue-yellow" color opponent system that is the evolutionary homolog of the blue-ON division of the koniocellular pathway in primates.
\end{abstract}

\section{Introduction}

Most humans and many other primate species enjoy trichromatic color vision based on the activity of three cone photoreceptor types with maximum sensitivity in the short-wavelength (S) (or "blue"), medium-wavelength (M) (or "green"), and longwavelength (L) (or "red") bands of the visible spectrum. Full trichromatic color vision is, however, rare or absent from nearly all nonprimate mammalian species studied so far (Jacobs, 1993; Nathans, 1999). Most mammals express S-cones and a single cone type in the medium/long-wavelength (ML) band (Ahnelt and Kolb, 2000; Szél et al., 2000), and can make only dichromatic ("red-green color blind") spectral discriminations (Loop and Bruce, 1978; Loop et al., 1987; Jacobs et al., 2001; van Arsdel and Loop, 2004; Van Hooser and Nelson, 2006). The purpose of the present study is to investigate the transmission of nerve signals for the dichromatic "blue-yellow" axis of color vision in cats.

Received June 14, 2012; revised Nov. 13, 2012; accepted Nov. 18, 2012.

Author contributions: P.B., Z.P., I.T., P.R.M., and L.L. designed research; P.B., P.K., Z.P., and I.T. performed research; P.R.M. and L.L. contributed unpublished reagents/analytic tools; P.B., P.K., and Z.P. analyzed data; P.B., P.K., and P.R.M. wrote the paper.

This work was supported by Hungarian Scientific Research Fund (OTKA) Grant K79156 and the Bolyai Fellowship (P.B.), and by TÁMOP-4.2.1./B-10/2/KONV-2010-0002. We are indebted to Ulf T. Eysel and Zoltán F. Kisvárday for providing important equipment and to Peter Lennie and Samuel G. Solomon for providing the Expo software. We thank Ferenc Wilhelm, Erzsébet Korona, and Anna Schulteisz for technical assistance, and Joachim Brunner and Dirk Schumacher for help with recordings. The authors declare no competing financial interests.

Correspondence should be addressed to Péter Buzás, Institute of Physiology, Medical School, University of Pécs, Szigeti út 12,7624 Pécs, Hungary. E-mail: peter.buzas@aok.pte.hu.

DOI:10.1523/JNEUROSCI.2844-12.2013

Copyright $\odot 2013$ the authors $\quad 0270-6474 / 13 / 331451-11 \$ 15.00 / 0$
In primates, the major retinal cell type showing S-cone opponent responses is the blue-ON, small bistratified retinal ganglion cell (Dacey, 1993; Dacey and Lee, 1994), whose signals (as well as signals from less frequently encountered blue-OFF cells) travel via the koniocellular layers of the lateral geniculate nucleus (LGN) (White et al., 1998; Szmajda et al., 2006; Roy et al., 2009) to reach the supragranular layers of primary visual cortex (Chatterjee and Callaway, 2003).

Comparatively little is known about S-cone pathways in nonprimate mammals, but current evidence suggests that the S-cone opponent pathways of early mammals (and their current, nonprimate descendants) should be functionally similar to those found in primates (Yeh et al., 1995b; Lee et al., 2000; Solomon, 2002; Blessing et al., 2004; Martin et al., 2011). In the retinae of rodents (Haverkamp et al., 2005; Li and DeVries, 2006; Puller et al., 2011) and cats (Cohen and Sterling, 1990a,b), S-cones connect a specific bipolar cell type. Antagonistic responses to the activation of S- and ML-cones were demonstrated in several species including cats by recordings from retinal ganglion cells (Michael, 1966; Cleland and Levick, 1974; Vaney et al., 1981; Hemmi et al., 2002; Ekesten and Gouras, 2005; Yin et al., 2009) or from relay neurons of the LGN (Daw and Pearlman, 1970; Michail, 1973; Cleland et al., 1976; Wilson et al., 1976). Their spatial receptive field structure has not been studied systematically, and it is not known whether they constitute one or more coherent functional channels.

Here, in recordings from cat LGN, we searched for neurons that receive significant $S$-cone input and characterized their receptive fields using cone-selective gratings as previously used to 
study color selectivity in the primate visual system. We found a population of neurons with blue-ON receptive fields in the deep (C, C1, and C2) layers with similar properties to blue-ON receptive fields in monkey retina and the koniocellular layers of the monkey LGN. Based on these data, we suggest that cat blue-ON cells are part of a "blue-yellow" color opponent system that is the evolutionary homolog of the blue-ON division of the koniocellular pathway in primates.

\section{Materials and Methods}

Ethical approval. Experimental animals were kept and the experiments performed according to Hungarian and European legislation (Directive 2010/63/EU of the European Parliament and of the Council of 22 September 2010 on the Protection of Animals Used for Scientific Purposes). All procedures were approved by the Directorate for Food Chain Safety and Animal Health of the Baranya County Government Office.

Surgical preparation. Seven anesthetized $\left(\mathrm{N}_{2} \mathrm{O}\right.$ plus isoflurane), paralyzed (vecuronium bromide; Norcuron; Organon) and artificially ventilated adult cats (two females; five males) were used in the experiments. Anesthesia was induced with a mixture of ketamine ( $7 \mathrm{mg} / \mathrm{kg}$; Calypsol; Richter) and xylazine (1 mg/kg; CP-Pharma) intramuscularly. Anesthesia was maintained during surgery by additional doses of ketamine when needed. The eyes were protected against dehydration using contact lenses with zero optical power. The femoral artery was cannulated and a tracheal cannula implanted. A craniotomy of $\sim 5 \times 5 \mathrm{~mm}$ with its center at Horsley-Clarke coordinates of anteroposterior 4.7, lateral 9.2, was made for vertical access to the left LGN. For muscle relaxation, vecuronium bromide was infused with glucose $\left(24 \mathrm{mg} \cdot \mathrm{kg}^{-1} \cdot \mathrm{h}^{-1}\right)$ and Ringer's solution (B. Braun) via the femoral catheter. Cats were ventilated artificially with a $1: 2$ mixture of $\mathrm{O}_{2}$ and $\mathrm{N}_{2} \mathrm{O}$ supplemented with $0.5-2.5 \%$ isoflurane (CP-Pharma) to maintain anesthesia throughout the experiment. General physiological parameters were monitored and kept in normal ranges (end-tidal $\mathrm{CO}_{2}, 3-4 \%$; blood pressure, $100-140 \mathrm{mmHg}$ peak; body temperature, $38^{\circ} \mathrm{C}$ ).

Visual stimuli. Visual stimuli were generated using Open GL commands controlled via freely available software (Expo; courtesy of Peter Lennie, University of Rochester, Rochester, NY) running on an Apple Power Mac G5 computer and presented on a computer monitor (IBM P275; frame refresh rate, $96 \mathrm{~Hz}$ ) at 28.5 or $57 \mathrm{~cm}$ from the cat's eyes. Where necessary, the monitor was moved parallel to the screen to the receptive field (RF), thus simulating the use of a large tangent screen. Reported stimulus size is not corrected for the small changes in viewing distance caused by these shifts. Stimuli were circular patches whose color and contrast were calibrated to modulate either both cone types together (achromatic stimuli) or S-cones or ML-cones (cone-isolating stimuli). Cone nomograms (Lamb, 1995) for cat photopigments were calculated using peak absorption wavelengths of $450 \mathrm{~nm}$ (Guenther and Zrenner, 1993 ) and $553 \mathrm{~nm}$ (Yokoyama and Radlwimmer, 1999) for S- and MLcones, respectively. Cone-isolating stimuli were generated by transforming feline S- and feline ML-cone contrast to red-green-blue (RGB) coordinates of the display. The color transformation matrix was obtained by calculating the inner product of the cone nomograms with the spectral power distributions of the linearized R, G, and B phosphors of the display. Spectrophotometric measurements were done using a PR-705 spectroradiometer (Photo Research).

The screen had a mean photopic luminance of $42 \mathrm{~cd} / \mathrm{m}^{2}$. Light levels of $>10 \mathrm{~cd} / \mathrm{m}^{2}$ can be considered to be photopic for the cat (Loop et al., 1987). The pupils were dilated with $1 \%$ atropine sulfate and glass lenses were placed in front of the cat's eyes to focus the reflected image of the tapetum lucidum onto the stimulus monitor. On encountering the first well isolated single unit, the correction lens was adjusted so as to maximize the spatial frequency cutoff of its receptive field for achromatic gratings. This procedure was performed for each eye separately.

Search strategy. The major goal of the study was to identify and characterize neurons in the cat LGN responding to modulation of S- ("blue") cones. Accordingly, we probed each recording location $(n=200)$ with achromatic and S-cone-isolating gratings of low spatial $(\sim 0.05$ cycles $\left.\mathrm{deg}^{-1}\right)$ and temporal $(\sim 3 \mathrm{~Hz})$ frequency as we moved along vertical
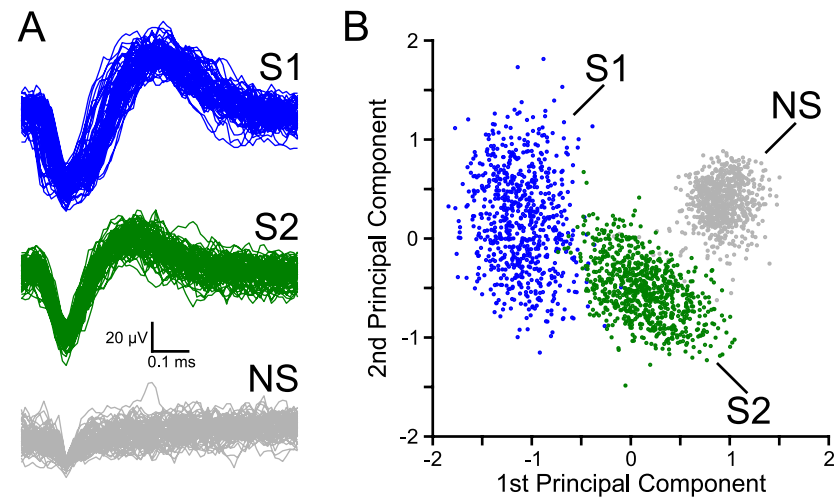

Figure 1. Separation of single units recorded with the same electrode. $A$, Waveforms of the isolated spikes of a blue- $\mathrm{ON}$ unit ( $\mathrm{S} 1$; blue) and an achromatic unit ( $\mathrm{2} 2$; green) from layer $\mathrm{C1}$ shown together with events classified as nonspikes (NS; gray). To reduce clutter, every 10th spike and every 80th nonspike are shown. $\boldsymbol{B}$, Scatterplot of the first two principal components of waveforms in the same sample. Similar plots were used during experiments to outline clusters of waveforms belonging to single units. The principal component analysis was done on all waveforms crossing trigger level. Three clusters are clearly visible, two of which were classified as spikes (S1, blue; $\mathrm{S} 2$, green) and one as nonspikes (NS, gray) after inspecting their waveforms as shown in $\boldsymbol{A}$.

penetrations $(n=43)$ through the LGN. If a cell could be heard on the audio monitor to respond to the S-cone-isolating stimulus, we always attempted to isolate and characterize all single units based on their spike shape (see below) at that location. Additionally, units without any apparent S-cone response were also picked up and characterized using the same battery of tests for comparison. Together, we isolated 201 units at 85 locations. We could confirm specific S-cone responses of 23 units at 21 of these locations. Forty-five neurons ( 14 blue-ON cells and 31 achromatic cells) had sufficiently complete datasets to be included in the present report.

Single-unit electrophysiology. Extracellular potentials were bandpass filtered between 700 and $5000 \mathrm{~Hz}$, amplified and digitized at 22 or $48 \mathrm{kHz}$ using an external sound card connected via serial port to the same computer generating the visual stimuli. Action potentials of single units were separated using principal component analysis of the waveforms as follows.

At each recording site, we first applied a stimulus that elicited maximal multiunit response, as judged by listening to the audio monitor and viewing the waveforms of events crossing trigger level. We found it often useful to adjust trigger level so that noise crossed trigger at approximately an equal frequency as did spikes. We collected clips of event waveforms containing entire action potentials and performed principal component analysis of the last 500 of them. Typically, the first two principal components were plotted and single units were defined by drawing nonoverlapping polygons around well isolated clusters of points. We classified all subsequent events from the same recording site as belonging to either one of these clusters or as nonspikes. This procedure allowed the separation of, on average, 1.3 units per recording site ( 1 unit at 25 recording sites, 2 units at 8 recording sites, and 4 units at 1 recording site). Figure 1 shows the analysis of a typical spike separation. The spike shapes (Fig. $1 \mathrm{~A}$ ) were classified in three clusters on the basis of the first two principal components when we first encountered this group of cells. Figure $1 B$ is a similar principal component plot of events collected 10-25 min later showing that the initial classification was still valid.

To estimate the frequency of false positives (i.e., events misclassified as belonging to a certain spike cluster), we calculated the percentage of refractory time violations. Interspike intervals of $<2.5 \mathrm{~ms}$ occurred in $1.46 \pm 4.91 \%$ of the events (geometric mean and SD; $n=45$ ) showing that false positives had but a minor contribution to our results.

The amplitude of spike rate modulation with the stimulus frequency was determined by Fourier analysis and used as response measure.

Histology. At the end of each experiment, animals were overanesthetized using 5\% isoflurane, killed using T61 (Intervet), and then perfused 
through the left ventricle with $0.1 \mathrm{~m}$ phosphate buffer, $\mathrm{pH} 7.4$, followed by $4 \%$ paraformaldehyde prepared in the same buffer. Tissue blocks containing the LGN were removed then cryoprotected in 30\% sucrose. Frozen sections of $40 \mu \mathrm{m}$ thickness were cut in the frontal plane and stained using cresyl violet stain. The location of electrode tracks was determined in the light microscope. Only units that were recorded along a track passing through the laminated part of the dorsal lateral geniculate nucleus were included in the dataset.

Testing the receptive field. At each recording location, we first determined the dominant eye, that is, the eye through which visual stimulation evoked single or multiunit activity of higher amplitude. The depth where receptive fields were clearly contralateral and their location well defined within a few degrees of visual field was taken as the start of layer A. From here, systematic change of the dominant eye indicated the successive layers A1, C, C1, and C2. In some of the tracks, we could not isolate units from the deepest one or two layers. The nondominant eye was covered for further characterization of the receptive field.

The stimuli were centered on the receptive field of the cell (or that of the unit with the most vigorous discharge if multiple spikes were isolated at the same location) by moving the stimulus patch on the screen and gradually decreasing its size. The diameter of the patch was then set at a value between 10 and $30^{\circ}$ (average, 19.5) for the remaining of tests at the given recording site. We chose these large patch sizes because (1) behavioral data (Loop et al., 1979) indicated that the cat's color vision system is extremely low-pass and (2) to include any receptive field surrounds for complete characterization of spatial frequency tuning. Analysis of the spatial frequency response of the cells (see below) showed that stimuli were $4.8 \pm 3.4$ times (geometric mean $\pm \mathrm{SD} ; n=44$ ) larger than the receptive field size of the same cell, including surround. We next tested cone inputs qualitatively using spatially uniform, square-wave modulated achromatic and cone-isolating stimuli (see Fig. 2). In the first, exploratory one-half of the study ( 22 units), temporal frequency was set to $5 \mathrm{~Hz}$ for the remaining tests. In later experiments ( 23 units), temporal frequency tuning was determined using spatially uniform achromatic (for achromatic cells) or S-cone-isolating (for blue-ON cells) stimuli, and the optimal frequency was used for subsequent tests. Temporal frequencies tested were as follows: $0.5,1,2,4,6,8,12,16,32,48 \mathrm{~Hz}$. Finally, contrast response and spatial frequency tuning were measured as described below.

Estimating contrast gain. Contrast response functions were characterized using spatially uniform circular patches with contrast modulated sinusoidally in time. It is known that contrast response depends on many stimulus parameters including spatial and temporal frequency (EnrothCugell et al., 1983). Here, we used uniform fields because our main purpose was to compare achromatic and S-cone sensitivities under equal conditions, using stimuli comparable with previous studies of S-cone contrast response in primates (Lee et al., 1990; Yeh et al., 1995a; Tailby et al., 2008a,b).

Contrast gain was estimated from the slope of the contrast response (spikes $\cdot$ second ${ }^{-1}$; see Fig. 3 ) over the contrast range of $0-70 \%(n=34)$ or $0-50 \%(n=8)$. In four cells that showed suppression of the response at high contrast (supersaturation), we estimated gain over the contrast range from $0 \%$ to maximum response. We applied a stepwise fit procedure to estimate contrast gain as follows. Four analytic functions with increasing complexity (that is, increasing numbers of free parameters) were applied to each contrast-response curve, and residual errors for each function were calculated. The simplest model that significantly reduced residual error over its predecessor ( $p<0.1, F$ test) was used. Least-squares optimization was performed using the Solver module in Microsoft Excel. The functions used were as follows: (1) No significant response ( $p \geq 0.1$, single-factor ANOVA) meaning gain was zero. (2) Linear relationship $(R=a C+b)$. Here, contrast gain equaled the slope $a$ of the line. (3) Simple Naka-Rushton model (Naka and Rushton, 1966) ( $n=1$ in Eq. 1, given below). Here, gain $=R_{\max } / C_{50}$ (Croner and Kaplan, 1995). (4) Expansive Naka-Rushton model (Naka and Rushton, 1966) is as follows:

$$
R=R_{\max } \frac{C^{n}}{C_{50}^{n}+C^{n}}+b
$$

where $R$ was the response of the cell at contrast $C$, and $R_{\max }, C_{50}, n$, and $b$ were parameters free to vary. This form allows for an expansive buildup of response at lower contrasts, which is followed by saturation at high contrasts (see Fig. 3A) (Albrecht and Hamilton, 1982; Duong and Freeman, 2008). Contrast gain was the maximum of the first derivative of Eq. 1 as follows:

$$
\frac{d R}{d C}=a n \frac{C^{n-1} d^{n}}{\left(d^{n}+C^{n}\right)^{2}} .
$$

Determining receptive field dimensions from the spatial frequency response. One of the chief purposes of this study was to determine the size of receptive field regions providing input to each cell via S- or ML-cones. To this end, we measured the spatial frequency response of each cell using both S- and ML-cone-isolating stimuli (see Fig. 5). Spatial frequencies tested were $0,0.01,0.02,0.05,0.1,0.2,0.4,0.8,1.6,3.2,6.4$ cycles $\cdot \mathrm{deg}^{-1}$. Stimulus size and temporal frequency were equal to that used for contrast response measurement. Generally, the spatial frequency response of an LGN relay cell can be described by the difference-of-Gaussians (DOG) model (Enroth-Cugell and Robson, 1966) as follows:

$$
R=R_{e}-R_{i}
$$

where $R_{e}$ and $R_{i}$ are responses of the excitatory and inhibitory regions following the form:

$$
R_{x}=K_{x} r_{x}^{2} \pi e^{-\left(r_{x} \pi f\right)^{2}}
$$

Here, $K_{x}$ is the sensitivity, $r_{x}$ is the radius of the receptive field region, and $f$ is the spatial frequency of the stimulus in cycles $\cdot \operatorname{deg}^{-1}$. We used the stepwise fitting procedure described above to determine whether responses were better fit by a single Gaussian (Eq. 4) or the full DOG model (Eq. 3).

\section{Results}

\section{Achromatic and S-cone responses}

Together, 45 neurons are included in the present analysis (32 in the magnocellular layers $\mathrm{A}, \mathrm{A} 1$, and $\mathrm{C}, 11$ in the parvocellular layers $\mathrm{C} 1$ and $\mathrm{C} 2$, and 2 undetermined). The laminar location of units was indicated by the systematic change in the eye through which responses could be evoked (also see Materials and Methods). At most recording sites, achromatic stimuli evoked strong multiunit ("swish") activity, whereas the S-cone-isolating stimulus minimized the multiunit response as if contrast was decreased to zero. Figure $2 \mathrm{~A}$ shows peristimulus time histograms of spike responses recorded from a single cell in layer A1. Increments and decrements of achromatic contrast elicited transient $\mathrm{ON}$ and OFF responses, respectively, in this cell. Modulating ML-cones in isolation evoked similar responses, whereas the S-cone-isolating stimulus had no detectable effect on the spike rate. This suggests that the achromatic response was in fact due to stimulation of ML-cones alone.

On rare occasions (21 of 200 recording sites tested), the S-cone-isolating search stimulus caused clear modulation of the spike rates of one or more single units, while the activity of the other units was minimized. Responses of an isolated S-cone responsive unit from layer $\mathrm{C}$ are shown in Figure $2 \mathrm{~B}$. Here, the achromatic stimulus evokes only a slight elevation in the $\mathrm{ON}$ phase of the stimulus. However, the same cell shows a tonic OFF response to the ML-cone-isolating stimulus and a tonic ON response to the S-cone-isolating stimulus. Moreover, the amplitudes of the cone-isolating responses appear nearly equal at equal cone contrast. This suggests that the achromatic response is minimal because equal and opposite functional inputs from the two cone types cancelled each other. 

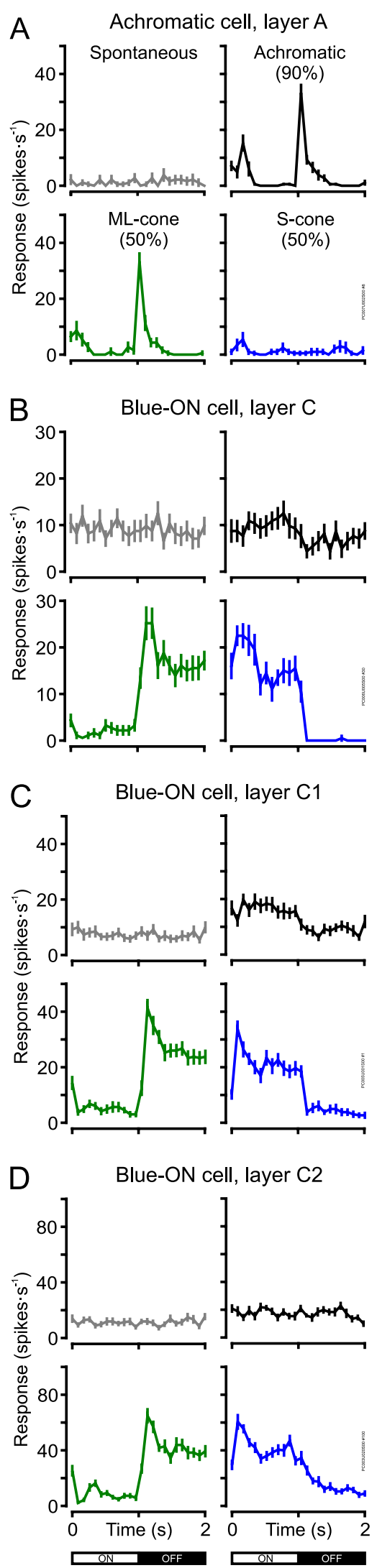

Figure 2. Peristimulus time histograms (PSTHs) of responses of single units from the cat LGN to square-wave increments (ON) and decrements (OFF) of contrast. Spontaneous activity and responses to $90 \%$ achromatic, $50 \% \mathrm{ML}$-cone and $50 \% \mathrm{~S}$-cone-isolating contrast are shown for each single unit as labeled in $\boldsymbol{A}$. Error bars show SEM. $\boldsymbol{A}$, Achromatic unit from layer $A$ showing transient $\mathrm{ON}$ and $\mathrm{OFF}$ responses to achromatic and $\mathrm{ML}$-cone contrast changes. Note that $\mathrm{S}$-cone

\section{Contrast response}

The obvious difference between the example cells shown in Figure 2 is their differential preference for achromatic and S-cone-isolating stimuli. We measured the contrast dependence of the response and estimated contrast gain using the stepwise fitting procedure described in Materials and Methods. Example responses and fits are shown in Figure 3, $A$ and $B$. Most recorded cells were similar to the example shown in Figure $3 A$ (a cell from layer A of the LGN), where increasing achromatic contrast resulted in a steep buildup of the response followed by saturation at higher contrasts. This cell reaches its maximal contrast gain ( 1.37 spikes $\left.\cdot \mathrm{s}^{-1} \cdot \%^{-1}\right)$ at $4.7 \%$ contrast. The same cell was considerably less sensitive to $\mathrm{S}$-cone contrast; the contrast response relationship for S-cones was closely linear with a slope of 0.075 spikes $\cdot \mathrm{s}^{-1} \cdot \%^{-1}$ : this value is $\sim 1 / 19$ of the achromatic contrast gain.

A minority of cells in our sample ( 14 of $45 ; 31 \%)$ showed vigorous responses to S-cone contrast; an example is shown in Figure $3 B$. The S-cone contrast gain was 0.1 spikes $\cdot \mathrm{s}^{-1} \cdot \%^{-1}$, whereas achromatic contrast evoked no significant change in response (ANOVA, $p=0.33$ ); therefore its ML-cone contrast gain was set to zero.

The achromatic and S-cone contrast gain values of the entire sample are compared on the scatterplot in Figure 3C. The reader should note that contrast gain values of zero are plotted beside the logarithmic scale. This convention might create the visual impression of three clusters: cells with absolutely no achromatic response, cells with absolutely no S-cone response, and cells with a mix of achromatic and S-cone responses. However, the lowest nonzero gain values are only slightly higher than zero, and there is a continuum between cells with very low achromatic or S-cone sensitivity and the cells assigned zero gain by our stepwise fit procedure. Overall, there is a weak negative correlation between achromatic and S-cone contrast gains, suggesting opposite preference of the cells for these stimuli (Pearson's $r=-0.33, p=$ 0.029 , calculated by replacing zero gain values with 0.01 spikes $\cdot \mathrm{s}^{-1} \cdot \%^{-1}$ and $\log$-transforming the data).

The line where S-cone sensitivity exceeds achromatic sensitivity can be thought of as separating two mechanisms with different functions in vision. If a cell is more sensitive to the achromatic stimulus (which stimulates both ML- and S-cones) than it is to modulation of S-cones alone, then this indicates additive inputs from the two cone types. However, if the cell is more sensitive to $\mathrm{S}$-cone modulation than to the achromatic stimulus, this indicates opponent input from the two spectral cone types.

We have defined cells above the diagonal in Figure $3 C$ as "blue-ON cells" $(n=14)$ and those below the diagonal as "achromatic cells" $(n=31)$. The definition might seem arbitrary at this point, but we present further evidence hereinafter that blue-ON cells are a distinct population in cat LGN. By definition, each cell group has higher contrast gain for its preferred stimulus. The median achromatic contrast gain for achromatic cells was 0.86 spikes $\cdot \mathrm{s}^{-1} \cdot \%^{-1}$, and the median S-cone contrast gain for blue-ON cells was 0.22 spikes $\cdot \mathrm{s}^{-1} \cdot \%^{-1}$.

It could be argued that separating X-and Y-cells would be a useful addition to our study. Finding a reliable diagnostic mea-

contrast has no effect on the spike rate. Eccentricity, $9^{\circ}$; preferred temporal frequency (TF), $8 \mathrm{~Hz}$ $\mathrm{RF}$ center radius, $0.26^{\circ}$. $\boldsymbol{B}-\boldsymbol{D}$, Blue- $0 \mathrm{~N}$ cells from layers $\mathrm{C}, \mathrm{C} 1$, and $\mathrm{C} 2$, respectively, showing weak response to achromatic contrast and opponent $\mathrm{OFF}$ and $\mathrm{ON}$ responses to $\mathrm{ML}$ - and $\mathrm{S}$-cone contrast. $\boldsymbol{B}$, Eccentricity, $11^{\circ}$; preferred TF, $16 \mathrm{~Hz}$; RF center radius, $1.22^{\circ}$. C, Eccentricity, $29^{\circ}$; preferred TF, $8 \mathrm{~Hz}$; RF center radius, $2.26^{\circ}$. D. Eccentricity, 54 ; preferred TF, $4 \mathrm{~Hz}$; RF center radius, $1.99^{\circ}$. 
A
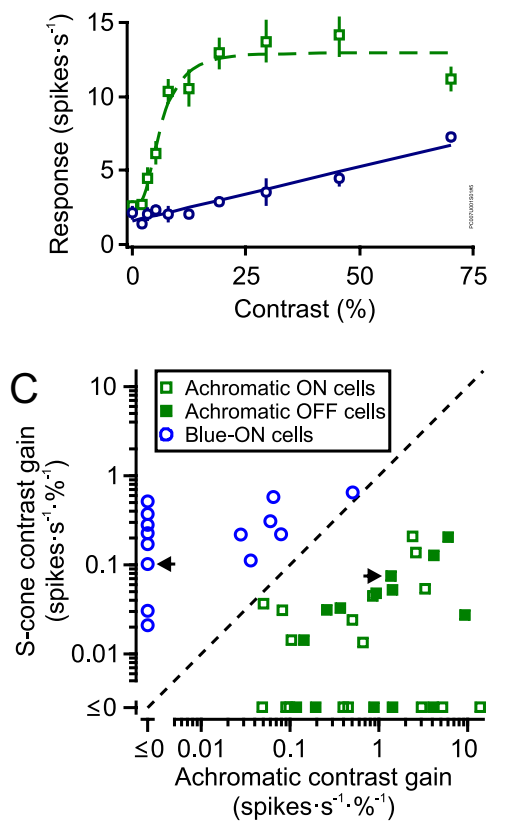

Figure 3. Achromatic and S-cone contrast responses of single units measured with sine wave temporal modulation. A, Achromatic cell from layer A showing high contrast gain and strong saturation for achromatic stimuli (green squares) and low contrast gain for S-cone-isolating stimuli (blue circles). Error bars show SEM. Curves show the best fit contrast response functions for achromatic (broken green line) and S-cone-isolating (solid blue line) conditions, respectively. Eccentricity, $10^{\circ}$; temporal frequency, $5 \mathrm{~Hz}$. B, Same as $\boldsymbol{A}$ but for a blue- $0 \mathrm{~N}$ cell in layer $\mathrm{C1}$. This cell shows higher contrast gain and linearly increasing response for S-cone-isolating stimuli (blue) and nonsignificant change in response with achromatic contrast (green). Eccentricity, $12^{\circ}$; temporal frequency, $2 \mathrm{~Hz}$. C, Comparison of contrast gains for achromatic and S-cone-isolating stimuli for all 45 single units of the study. Positive values are shown on a log-log scale, data points with zero (or for one cell, negative) contrast gains are plotted at the low end of the axes. The dashed line indicates equal achromatic and S-cone contrast gains. Cells below this diagonal were classified as achromatic cells (green squares), whereas those above the diagonal were classified as blue- $\mathrm{ON}$ cells (blue circles). The open symbols indicate $\mathrm{ON}$ cells, and the filled symbols indicate $\mathrm{OFF}$ cells. The arrows indicate the single units shown in $\boldsymbol{A}$ and $\boldsymbol{B}$. D. The gray lines show superimposed contrast responses of achromatic (top panel, $n=26$ ) and blue-ON cells (bottom panel, $n=12$ ). Responses were obtained with the preferred stimulus of the cells, i.e., achromatic for achromatic cells and S-cone isolating for blue- $\mathrm{ON}$ cells. Curves are normalized to have a maximum of 1 and zero response at zero contrast. The black lines show average normalized responses. Saturation and even supersaturation is common for achromatic cells, whereas the curves of S-cone cells are closer to linearity.

sure was, however, not easy. It is clear from Figure $3 C$ that the achromatic cell group does not split into clusters with high and low contrast gain, which we may identify with $\mathrm{X}$ - and Y-types. Furthermore, contrast gain is known to depend on a number of factors including eccentricity and RF size. The null test is useful to identify linear and nonlinear cell types, but these groups are known to exist within the $\mathrm{W}$-cell population (Sur and Sherman, 1982), which likely has also contributed to our achromatic cell sample. The only unequivocal diagnostic to our knowledge is the measurement of axonal conduction velocity, but we did not make this measurement.

Many of the blue-ON cells showed a linear contrast response (Fig. 3D, bottom panel). In 6 of the 12 cases in which the full $\mathrm{S}$-cone contrast response was measured, the best contrast model found by stepwise fitting was linear. Achromatic cells, however, typically showed saturation at higher contrasts (Fig. 3D, top pan$\mathrm{el}$ ); the best model for $85 \%$ ( 22 of 26 ) achromatic contrast responses was saturating or supersaturating (also see Materials and Methods).

It is evident from Figure $3 C$ that the most sensitive achromatic cells reached S-cone gains typical of the blue-ON cell group. Moreover, when the achromatic cell group (Fig. 3C, squares) was regarded alone, achromatic and S-cone gains were positively cor- related $(r=0.35, p \approx 0.054$ after log transformation). An example of this can be seen in Figure $3 A$, where the achromatic cell shows a linear S-cone response reaching a maximum at $70 \%$ S-cone contrast; this response was equivalent of $5.7 \%$ achromatic contrast as determined from the inverse of the achromatic contrast response function. There are two simple explanations for these findings. One would be a small S-cone input to the RFs of achromatic cells added to the ML-cone input. An alternative possibility is some residual stimulation of the nominally silenced cone type, that is, an ML-cone artifact in the $\mathrm{S}$-cone-isolating stimulus. In both cases, the responses to the $\mathrm{S}$-cone stimulus would increase with increasing achromatic sensitivity of the cell. We cannot rule out either possibility, but our further analysis does not depend on the cause of $\mathrm{S}$-cone responses in achromatic cells.

\section{Laminar distribution}

We tested altogether 200 recording sites using S-cone-isolating stimuli in the LGN. Units with preferential S-cone responses were generally rare (found in $10.5 \%$ of the sites tested) (also see Materials and Methods, Search strategy), and they always occurred together with achromatic ones. These had to be separated on the basis of their spike waveforms (see Materials and Methods).

As Figure 4 illustrates, the blue-ON cells of our present sample are all from layer $\mathrm{C}$ or from the two parvocellular layers $\mathrm{C} 1$ and $\mathrm{C} 2$ and were never encountered in the upper two (A and A1) layers. It is important to note that the graph does not represent proportions of blue-ON cells in the entire population of LGN cells because we actively searched for them using $\mathrm{S}$-cone-isolating stimuli. The segregation of S-cone responses to the deep layers suggests that these cells may constitute an anatomically separate group. The laminar distribution of our blue-ON cells corresponds to the distribution of $\mathrm{W}$-type relay cells (Cleland et al., 1976; Wilson et al., 1976), a heterogeneous cell group mainly defined by their afferentation from slow conducting retinal axons.

We did not find significant differences $(p>0.37$ in all following $t$ tests) in S-cone or achromatic contrast gains, spatial frequency low-cut ratios, or normalized receptive field sizes of blue-ON cells between the magnocellular (C) and parvocellular (C1, C2) laminae. Thus, our data do not show evidence for further anatomical segregation of response properties among blue-ON cells.

\section{Spatial frequency response}

For all cells but one $(n=44)$, we recorded spatial frequency transfer functions for ML-cone-isolating as well as for achromatic and S-cone-isolating gratings (Fig. 5). All stimuli had equal cone contrasts so that the achromatic stimulus was equivalent to the superposition of the S- and ML-specific stimuli. These mea- 
A
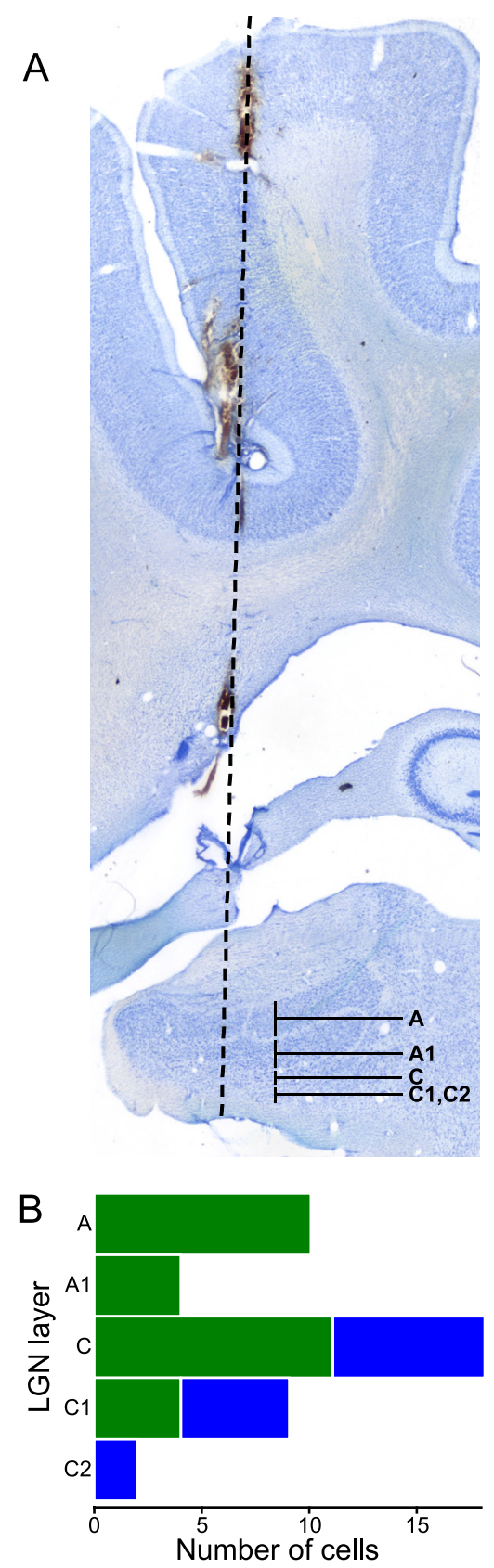

Figure 4. A, Cresyl-violet-stained frontal section of the brain of cat PCO06 showing traces of multiple electrode penetrations passing through the lateral half of the lateral geniculate nucleus. Layers are indicated by solid vertical lines. The course of a single track is shown by broken line. The left hemisphere is shown; lateral direction is to the left. $\boldsymbol{B}$, Laminar distribution of achromatic (green) and blue- $0 \mathrm{~N}$ cells (blue) in the present study $(n=43)$. Note that we actively searched for blue-ON cells; thus, our sample is biased. The blue- $\mathrm{ON}$ cells were only found in layers C, C1, and C2.

surements allowed spatiochromatic decomposition of the receptive field into two spatial (center and surround) and two chromatic (ML- and S-cone) components. Here, we refer by center and surround to the spatial extent and not to the excitatory or inhibitory nature of these mechanisms. The data were used to evaluate (1) the relative weights of functional inputs from the two cone types to the receptive field centers, (2) the sign (ON or OFF) and phase of these inputs relative to the stimulus, and (3) the relative sizes of the chromatic receptive field components. Figure $5 \mathrm{~A}$ illustrates the general result obtained from achromatic cells.
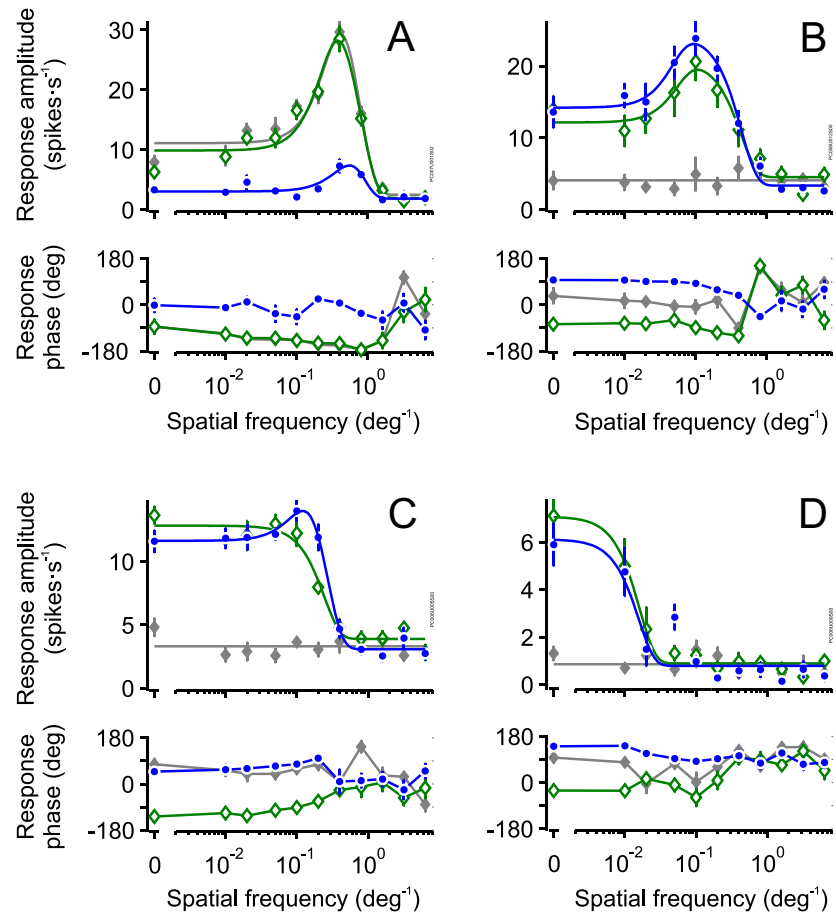

Figure 5. Spatial frequency responses of single units. $\boldsymbol{A}$, Response amplitude (top panel) and phase (bottom panel) of an achromatic cell from layer A of the LGN recorded for achromatic (gray diamonds), ML-cone-isolating (green diamonds), and S-cone-isolating (blue circles) sine wave gratings. Error bars show SEM. The solid lines in the top panel show the best fit spatial frequency response functions for each condition. The solid lines in the bottom panel connect data points. Receptive field eccentricity, $10^{\circ}$. $\boldsymbol{B}-\boldsymbol{D}$, Same as $\boldsymbol{A}$ but for blue- $0 \mathrm{~N}$ cells. Note the opposite response phases for ML-cone-isolating (green diamonds) and S-cone-isolating (blue circles) responses as well as the lack of significant achromatic responses (gray). Receptive field eccentricities were $10,9,11$, and $11^{\circ}$, respectively.

In this group, the responses can be explained by assuming only ML-cone input to the receptive field: achromatic response amplitudes were statistically indistinguishable from ML-coneisolating responses in all achromatic cells at all spatial frequencies (Student's paired $t$ tests between the two conditions showed $p>$ $0.01)$. The S-cone-isolating stimuli rarely evoked response in these cells.

The continuous curves in Figure $5 \mathrm{~A}$ are least-squares fits of the standard DOG model (Rodieck, 1965; Enroth-Cugell and Robson, 1966). The bandpass characteristics seen in the data are well approximated by the DOG model in this case, and the twocomponent DOG model gave the best account of frequency response in $71 \%$ of achromatic cells ( 22 of 31 ). For the remaining cells, the response was best described by a one-component (center-only) model as reported previously (Sur and Sherman, 1982; Enroth-Cugell and Freeman, 1987; Rowe and Cox, 1993). Figure $5 B-D$ shows spatial frequency responses of three blue-ON cells. A common property was their very weak achromatic response, which in approximately one-half of the cases (7 of 13 cells), did not show any statistically significant variation with spatial frequency (ANOVA, $p>0.1$ ). The S- or ML-coneisolating stimuli were always effective in blue-ON cells, although the shape of their spatial frequency characteristics showed substantial diversity. In 10 of the 13 cells tested, S-cone-isolating gratings produced bandpass tuning curves; in 4 of them, MLgratings showed similarly bandpass characteristics (Fig. 5B). Six 


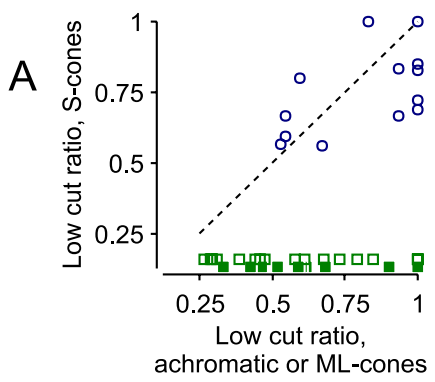

B Achromatic cells $\mathrm{C}$ Blue-ON cells
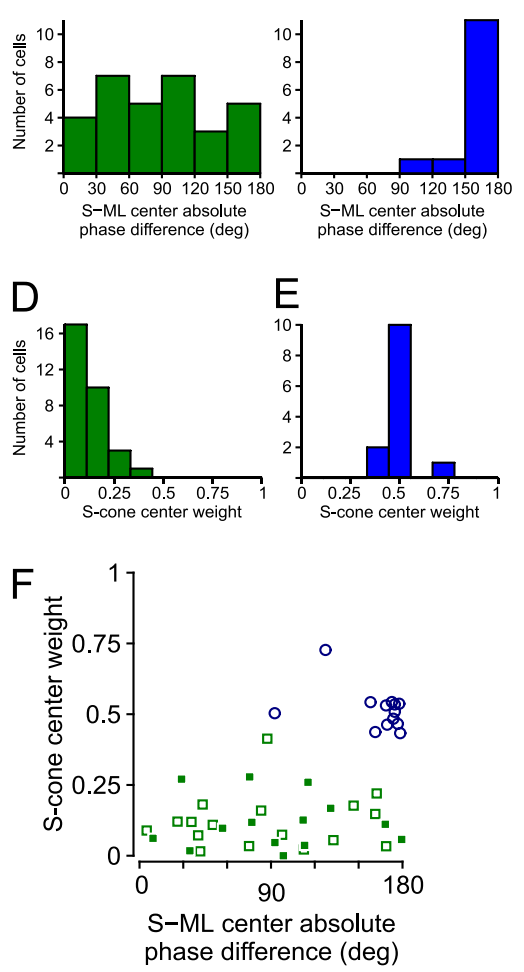

Figure 6. A, Strength of surround inhibition as shown by the low-cut ratio, which ranges from zero (complete response suppression at zero spatial frequency) to 1 (no response suppression at zero spatial frequency). Values were obtained using achromatic gratings for achromatic cells and using ML-cone-isolating (abscissa) and S-cone-isolating (ordinate) gratings for blue-0N cells. Symbols indicate cell type as in Figure 3C. Some data points for achromatic cells are slightly displaced for clarity. $\boldsymbol{B}-\boldsymbol{F}$, Relative phase $(\boldsymbol{B}, \boldsymbol{C})$ and weight $(\boldsymbol{D}, \boldsymbol{E})$ of $S$ - and $\mathrm{ML}$-coneisolating responses for achromatic $(\boldsymbol{B}, \boldsymbol{D})$ and blue-0N cells $(\boldsymbol{C}, \boldsymbol{E})$. $\boldsymbol{F}$, Comparison of the relative phases and weights of cone-isolating responses for each cell. Symbols indicate cell type as in Figure 3C. Note that blue-0N cells are tightly clustered around the point of opposite phase and equal $\mathrm{S}$ - and $\mathrm{ML}$-cone responses.

were similar to the example shown in Figure $5 C$, where MLgratings produced low-pass spatial frequency tuning. Low-pass tuning curves for S-cones, similar to that in Figure 5D, were found in three of the blue-ON cells.

Spatial antagonism in receptive fields can be quantified by the "low-cut ratio," which is the ratio of the responses to the lowest and the optimal spatial frequencies (Tailby et al., 2008b). Lowcut ratio is zero if the attenuation of the response is complete at low spatial frequencies, and it is 1 if the spatial frequency response is low pass. As shown in Figure 6A, the highest low-cut ratios (that is, most low-pass responses) were seen in the ML-cone fields of blue-ON cells $(0.81 \pm 0.20$; mean \pm SD) followed by their S-cone fields $(0.75 \pm 0.15)$. By contrast, achromatic cell re- sponses to achromatic gratings showed significantly more lowfrequency attenuation $(0.60 \pm 0.22, n=31$; Student's $t$ tests against ML- and S-cone fields of blue-ON cells: $p=0.0049, n=$ 13 , and $p=0.0309, n=13$, respectively). In summary, both chromatic components of blue-ON cell receptive fields can exhibit surround inhibition albeit weaker than usually seen in achromatic cells. Interestingly, low-cut ratios for S- and ML-cone components of blue-ON cell receptive fields (Fig. 6A, blue circles) were statistically similar to each other (Student's paired $t$ test, $p=0.2203$; Pearson's correlation, $r=0.55, p=0.0534, n=$ 13). This result shows these cells to balance their chromatic opponent spatial surrounds, which would, again, favor responses to color over achromatic stimuli.

\section{Sign and weight of the S-cone input}

In primates, the majority of S-cone-sensitive ganglion cells as well as such neurons of the LGN are blue-ON type because they show ON responses to increments of S-cone contrast (Malpeli and Schiller, 1978; Szmajda et al., 2006; Tailby et al., 2008a,b). Similarly, the few examples of color-coded neurons known from studies done in cats (Daw and Pearlman, 1970; Cleland and Levick, 1974; Wilson et al., 1976) showed mostly ON responses to blue light. Simple ON-OFF flashes (square-wave modulation) of $\mathrm{S}$-cone contrast evoked typically tonic ON responses in our sample of 14 blue-ON cells (Fig. 2 B). We determined response phases for S-cone modulation from the first harmonic Fourier component to zero spatial frequency modulation. Here too, we measured only $\mathrm{ON}$ responses (Figs. $2 B, 5 B-D$ ). This result is consistent with reported asymmetry in the representation of blue-cone contrast in the subcortical visual system of macaque and marmoset monkeys (Malpeli and Schiller, 1978; Szmajda et al., 2006; Tailby et al., 2008a,b). The ML-cone gratings evoked responses following the OFF phase of the stimulus (Figs. $2 B$, $5 B-D)$ in cat blue-ON cells. The difference between the response phases to S- and ML-cone-isolating gratings was narrowly distributed (Fig. 6C,F) and, on average, very close to $180^{\circ}(171.3 \pm$ $\left.26.6^{\circ} ; n=13\right)$ in the blue-ON cell population. A similar calculation for achromatic cells showed a mean phase difference of $80.2 \pm 74.8^{\circ}(n=31)$ and the S-versus ML-cone phase difference was evenly distributed (Fig. $6 B, F$ ). These results confirm that blue-ON cells in cat LGN give chromatically opponent responses.

Further support for the role of blue-ON cells in signaling color was found in the relative weights of S- and ML-cone inputs, calculated as $w_{\mathrm{S}}=R_{\mathrm{S}} /\left(R_{\mathrm{S}}+R_{\mathrm{ML}}\right)$, where $R_{\mathrm{S}}$ is the maximal first harmonic response amplitude for $\mathrm{S}$-cone-isolating gratings (i.e., response at optimal spatial frequency) and $R_{\mathrm{ML}}$ is maximal response for ML-cone-isolating gratings. Because we used the optimal spatial frequencies, this value characterized the predominant functional input to the receptive field center region. In achromatic cells, the low responsivity to $S$-cones was mirrored in low S-cone weights (median, $0.11 ; n=31$; Fig. $6 D, F$ ). The same calculation for blue-ON cells resulted in significantly higher values $(p<0.01$, Wilcoxon's rank sum test). In blue-ON cells, S-cone weights were narrowly distributed around 0.5 (median, $0.51 ; n=13$; Fig. $6 E, F)$, implying that the inputs from the two cone classes to the receptive field centers were well balanced. This result parallels our earlier findings on blue-ON cells of marmoset monkeys (Tailby et al., 2008b).

\section{Receptive field size and structure}

Behavioral studies indicate that the spatial resolution of S-cone vision in cats is much worse than it is for luminance stimuli (Berkley and Sprague, 1979; Loop et al., 1979). One reason for 
this may be that the density of S-cones is $\sim 1 / 5$ to $1 / 20$ of the ML-cone density in the central part of cat retina (Linberg et al., 2001). Thus, even if the color pathway is set up to achieve maximum spatial resolution, its receptive fields are expected to be larger than those of a high-acuity system sampling only from ML-cones. Further increase in receptive field size can result from neuronal convergence and optical blur.

By the application of cone-isolating gratings, we determined the sizes of both $\mathrm{S}$ - and ML-cone components of the recorded cells. Figure 7 shows that the receptive field centers of achromatic cells (median radius, $0.50^{\circ}$; Fig. $7 A, B$ ) are substantially smaller than the $\mathrm{S}$-cone radius (median, $1.99^{\circ}$; Fig. $7 \mathrm{~A}, \mathrm{C}$ ) or ML-cone radius (median, $2.30^{\circ}$; Fig. $7 A, D$ ) of blue-ON cell receptive fields (Wilcoxon's rank sum test, $p<0.001)$.

To estimate the relative size of achromatic and blue-ON receptive fields, we need to take into account the eccentricitydependent increase in receptive field size in cats (Fig. $8 \mathrm{~A}$ ). The dependence of receptive field size on eccentricity is well approximated by an exponential function (Troy, 1983; Enroth-Cugell and Freeman, 1987; Rowe and Cox, 1993). To obtain an estimate of this trend in our dataset, we fitted an exponential by leastsquares minimization to the receptive field center radii of achromatic cells (as determined using ML-cone-isolating gratings). The resulting regression line (equation $y=0.33 \mathrm{e}^{0.032 x}$ ), shown on semilog scale in Figure $8 A$, is approximately halfway between similar data series published for X-and Y-cells of cats (Troy, 1983; Enroth-Cugell and Freeman, 1987). The eccentricitydependent increase in RF radius was slightly less for blue-ON cells (equation $y=0.92 \mathrm{e}^{0.021 x}$ ).

We normalized the RF radii of each cell by dividing the actual radius in degrees by the radius expected for achromatic cells at the same eccentricity (Fig. $8 \mathrm{~A}$ ). For achromatic cells, the distribution of normalized radii was centered around 1 as expected (median, $1.02^{\circ} ; n=31$; Fig. $8 B$ ). The normalized RF center radii of blue-ON cells (Fig. 8C,D) were significantly larger, showing a median value of 2.60 and 2.77 for the S- and ML-cone fields, respectively ( $n=11 ; p<0.01$ in Wilcoxon's rank sum test against data of achromatic cells). Thus, blue-ON cells had receptive fields $\sim 2.7$ times greater than achromatic cells at any eccentricity.

The specialization of blue-ON cells for color vision in primates is, in part, supported by the similar spatial extent of the chromatic opponent mechanisms (Wiesel and Hubel, 1966). Our present data indicate that the S- and ML-cone fields of cat blue-ON cells are similar in size, as evidenced by their significant correlation (Fig. 7A; Pearson's correlation of log-transformed data, $r=0.75, p=0.0031, n=13$ ). Closer inspection reveals that $\mathrm{S}$-cone fields are slightly smaller (median S/ML radius ratio, 0.91 ), although the difference is on the margin of statistical significance (Wilcoxon's paired rank sum test, $p=0.08 ; n=13$ ). Thus, the spatial extents of S- and ML-cone-mediated excitatory inputs to cat blue-ON cells are essentially equal.

\section{Discussion}

Our results extend earlier findings in two respects. First, we show that $\mathrm{S}$-cone-responsive cells in the main visual relay nucleus of a
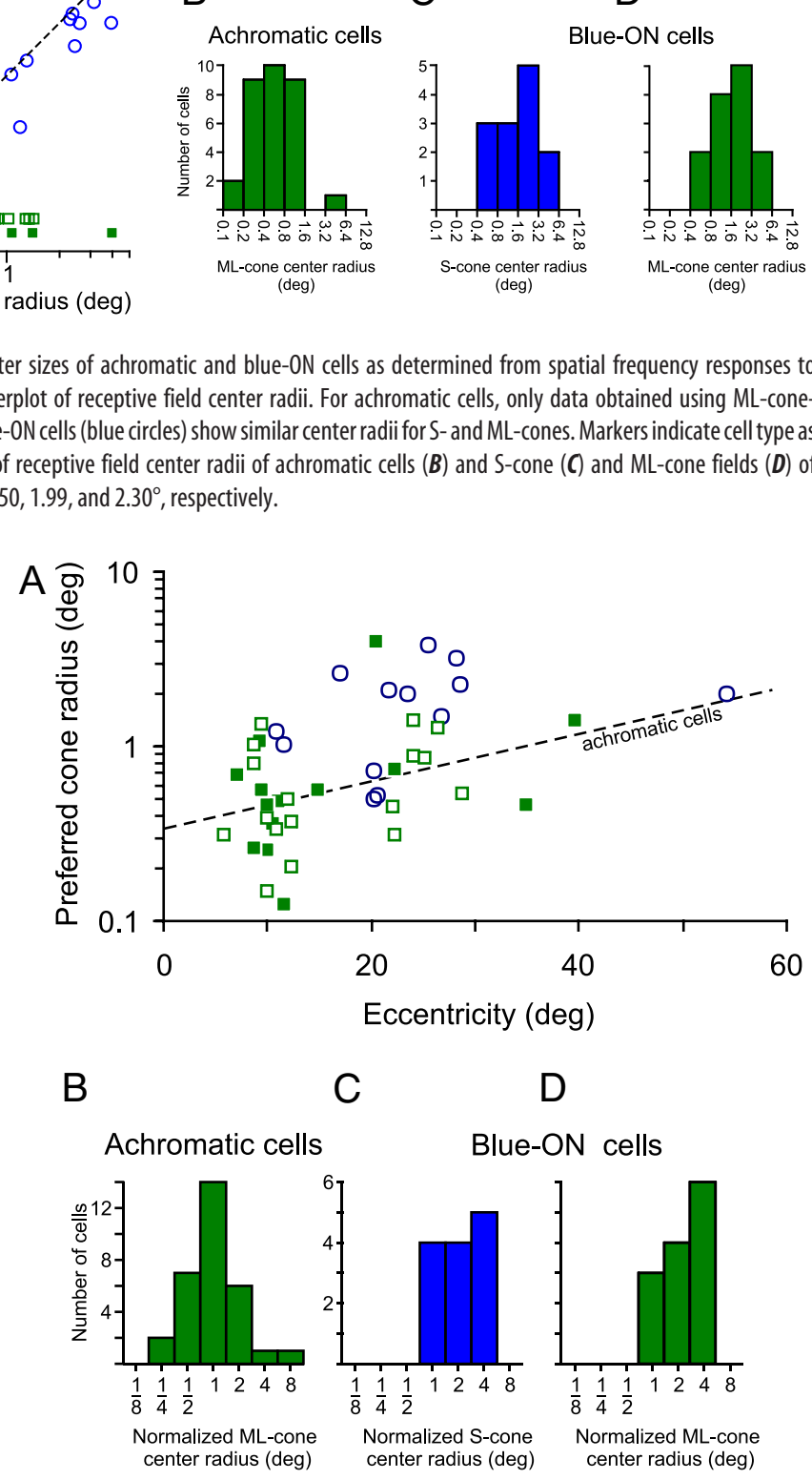

C

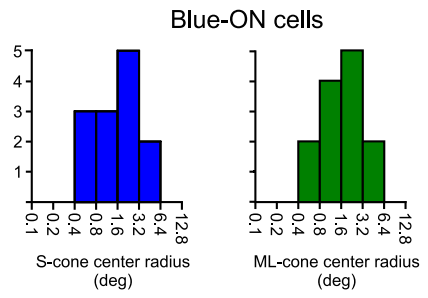

Figure 8. $\quad \boldsymbol{A}$, Receptive field center radius as a function of visual field eccentricity. Symbols indicate cell type as in Figure 3C. Regression line shows the increase of center radius of achromatic cells estimated with an exponential trend. $\boldsymbol{B}-\boldsymbol{D}$, Distribution of receptive field center radii normalized to the value expected at the corresponding eccentricity from the regression line in $\boldsymbol{A}$. $\boldsymbol{B}$, Achromatic cells, S-cone $(\boldsymbol{C})$, and ML-cone fields $(\boldsymbol{D})$ of blue-0N cells. Medians of normalized radii are $1.02,2.60$, and $2.77^{\circ}$, respectively.

nonprimate mammal constitute a functionally coherent population specialized for color vision. Second, the physiological properties of blue-ON cells in the cat LGN show strong functional similarity to blue-ON cells in monkeys. Therefore, our results support the view that the S-cone opponent pathway of nonprimate mammals is the evolutionary homolog of the blue-yellow $(\mathrm{S}-[\mathrm{L}+\mathrm{M}])$ opponent pathway of primates.

\section{Relay of blue cone signals in the cat LGN}

We aimed at creating conditions where only S- and ML-cones contributed to the stimulus-evoked responses. The influence of rods was minimized by applying photopic mean light levels of $>10 \mathrm{~cd} \cdot \mathrm{m}^{-2}$ (Loop et al., 1987). The isolation of each cone type 
can under these conditions be judged by considering how well the other cone type was silenced. The achromatic cell population showed very low sensitivity to the nominal S-cone-isolating modulation. The residual responses to the S-cone-isolating stimulus sometimes seen in these cells can be attributed to either weak S-cone input or to incomplete silencing of the ML-cone mechanism, possibilities that cannot be distinguished currently. The fact that blue-ON cells responded preferentially to the same stimulus that minimized the responses of achromatic cells, demonstrates that S-cone stimuli were effective in driving a second receptor mechanism.

It has been known since early studies of the cat visual system (Daw and Pearlman, 1970; Cleland and Levick, 1974; Wilson et al., 1976; Krüger, 1979; Rowe and Cox, 1993) that certain "colorcoded" retinal ganglion cells or thalamic relay cells respond vigorously to narrow-band blue light but are inhibited by longer wavelengths. Together, 13 examples of color-coded neurons are known from earlier studies of the cat LGN (Daw and Pearlman, 1970; Pearlman and Daw, 1970; Cleland et al., 1976; Wilson et al., 1976). Two features of the 14 blue-ON cells presented here matched the properties of those neurons, suggesting that we analyzed members of the same cell population. First, they receive spectral opponent input. Second, they are segregated to the C, C1, and C2 layers of the LGN. Together with previous results, our data suggest that blue-ON cells in LGN form the thalamic relay for cortical mechanisms serving color discrimination in cats (Loop and Bruce, 1978; Loop et al., 1979).

\section{Comparison to the primate S-cone system}

Our data reveal points of functional similarity between blue-ON cells in cats and monkeys. First, in our sample of blue-ON cells, the response to S-cone contrast increment was always ON-type. Blue-OFF cells may also exist in the cat, but they must be rare or difficult to record from, as reported consistently in recordings from monkeys or ground squirrel (Krüger, 1977; Malpeli and Schiller, 1978; de Monasterio, 1979; Valberg et al., 1986; Reid and Shapley, 2002; Chatterjee and Callaway, 2003; Lee et al., 2005; Szmajda et al., 2006; Tailby et al., 2008a,b; Chen and Li, 2012; Sher and DeVries, 2012). Thus, based on their frequency of occurrence, blue-ON cells are likely the major carriers of S-cone signals in the visual pathway of cats as well as primates.

Second, the contrast dependence of cat blue-ON cell responses resembled corresponding data from primates. Blue-ON cells in macaques and marmosets show nearly linear contrast response for S-cone-selective stimuli (Tailby et al., 2008a,b). We also observed only feeble responses to achromatic stimuli (Figs. $2 B, 3 B, 5 B-D)$ and balanced ML- and S-cone weights to the blue-ON cell center mechanism (Fig. 6B-F). The closely linear relationship between cone contrast and the response of the blue-ON cells (Fig. $3 B, D$ ) underlines their role in color vision because it allows efficient coding of the relative activities of the two cone types.

A third similarity between cat and monkey blue-ON receptive fields is their spatially coextensive S- and ML-cone inputs (Wiesel and Hubel, 1966; Chichilnisky and Baylor, 1999; Field et al., 2007; Crook et al., 2009). A classical example of this organization is the type II receptive field described in monkeys (Wiesel and Hubel, 1966), which is characterized by just two, perfectly overlapping chromatic opponent mechanisms. Such neurons favor chromatic contrast over spatial contrast because an achromatic stimulus of any spatial structure evokes responses of equal magnitude but opposite sign in the S- and ML-cone fields (Wiesel and Hubel, 1966; Livingstone and Hubel, 1984). The detailed receptive field structure of cat blue-ON cells is, however, more complex than the typical type II organization. In most cells (Figs. 5, 6A), we observed additional, mainly $\mathrm{S}$-cone-driven, surround inhibition. Similar inhibitory surrounds have been described in blue-ON cells of the primate LGN (Tailby et al., 2008a,b), although they are not normally manifest in their retinal ganglion cell counterparts (Dacey and Lee, 1994; Crook et al., 2009).

A few cells showed a comparable degree of low-frequency response attenuation by both cone types (Fig. 5B, 6A), which suggests receptive field organization known as "doubleopponent" (Pearlman and Daw, 1970; Livingstone and Hubel, 1984; Johnson et al., 2008). However, canonical examples of double-opponent cells show virtually complete low-frequency attenuation, whereas low-cut ratios of cat blue-ON cells always exceeded 0.5 (Fig. 6A). Regardless of these details, it can be concluded that the inputs from the two cone types to blue-ON cells are functionally well balanced, which is evidenced by their generally low achromatic sensitivity (Figs. 3, 5).

A final point of similarity of blue-ON cells in cats and in monkeys is their relatively large receptive field size compared with cells carrying luminance signals. In the retina of macaque monkeys and in the LGN of marmosets, blue-ON cells have receptive field center sizes $\sim 3$ times that of parvocellular cells and $\sim 1.5$ times that of magnocellular cells at the same eccentricity (Solomon et al., 2005; Tailby et al., 2008b); a comparable ratio between blue-ON and achromatic receptive field sizes (2.7) is seen in our dataset (Fig. 8).

\section{The primordial color system in cats}

It is reasonably assumed that all mammals possess an ancient "primordial subsystem" of color vision (Mollon, 1989; Jacobs, 1993), which in nonprimate mammals is based essentially on the same subcortical mechanism as the "blue-yellow" channel of trichromatic primates. This hypothesis is supported by studies of color vision of New World monkeys, whose populations comprise trichromatic and dichromatic individuals (Mollon et al., 1984). Physiological and anatomical experiments have shown that the downstream circuitry is independent of the number of manifest cone types in these animals (Yeh et al., 1995b; Lee et al., 2000; Solomon, 2002; Blessing et al., 2004; Telkes et al., 2008; Martin et al., 2011), suggesting that the circuitry was left unchanged by the diversification of the ML-cone opsin gene into multiple spectral types.

Color-coded neurons in cats are customarily attributed to the "third visual channel" represented by W-cells, comprising smallbodied neurons with slow conducting axons (Daw and Pearlman, 1970; Cleland and Levick, 1974; Cleland et al., 1976; Wilson et al., 1976). Although we did not classify our cells in the X, Y, and W categories, the laminar location of blue-ON cells in our sample (Fig. $4 B$ ) corresponds to that of the W-cell population (Stone and Hoffmann, 1972; Fukuda and Stone, 1975; Cleland et al., 1976; Wilson et al., 1976). It is interesting that we recorded most blue-ON cells in the magnocellular C-lamina, which contains a lower proportion of $\mathrm{W}$-cells $(40 \%)$ than do the parvocellular laminae C1 and C2 (100\%) (Cleland et al., 1976; Wilson et al., 1976). This may be due either to the much greater thickness of lamina $\mathrm{C}$ or to some anatomical segregation among different subtypes of W-cells.

Whereas our results support the view that S-cone opponent systems of various mammals follow a similar scheme (Mollon, 1989; Jacobs, 1993), general principles for all nonprimate orders are not yet established. A dedicated blue-cone bipolar cell type exists in mice (Haverkamp et al., 2005; Li and DeVries, 2006; 
Puller et al., 2011) and probably in rabbits (Famiglietti, 2008) and cats (Cohen and Sterling, 1990a,b), as well as in primates (Mariani, 1984; Kouyama and Marshak, 1992; Chan et al., 2001). Yin et al. (2009) describe a rarely encountered color opponent ganglion cell type in guinea pig retina that have monostratified morphology quite different than that of small bistratified cells in monkey retina. But the morphological correlate of the color-coded retinal ganglion cell in cats is yet to be found, and is an important gap in our knowledge of this otherwise best-studied mammalian visual system.

Little is known about the processing of chromatic opponent signals in the visual cortex of nonprimates (but see Polyanskii et al., 2006; Van Hooser and Nelson, 2006; Johnson et al., 2010). In general, blue-ON cells are best described as necessary but not sufficient to form a cortical representation of stimulus color because S-cone increments and ML-cone decrements result in equal changes in response of blue-ON cells. Based on the fact that other cells in the cat LGN had all or most of their input from ML-cones, the second dimension of the color space of the cat brain must be an achromatic one fed by ML-cones, similar to the luminance channel of primates. The comparison of the signals from distinct afferent streams is presumably a cortical process.

\section{References}

Ahnelt PK, Kolb H (2000) The mammalian photoreceptor mosaic-adaptive design. Prog Retin Eye Res 19:711-777. CrossRef Medline

Albrecht DG, Hamilton DB (1982) Striate cortex of monkey and cat: contrast response function. J Neurophysiol 48:217-237. Medline

Berkley MA, Sprague JM (1979) Striate cortex and visual acuity functions in the cat. J Comp Neurol 187:679-702. CrossRef Medline

Blessing EM, Solomon SG, Hashemi-Nezhad M, Morris BJ, Martin PR (2004) Chromatic and spatial properties of parvocellular cells in the lateral geniculate nucleus of the marmoset (Callithrix jacchus). J Physiol 557:229-245. CrossRef Medline

Chan TL, Martin PR, Clunas N, Grünert U (2001) Bipolar cell diversity in the primate retina: morphologic and immunocytochemical analysis of a New World monkey, the marmoset Callithrix jacchus. J Comp Neurol 437:219-239. CrossRef Medline

Chatterjee S, Callaway EM (2003) Parallel colour-opponent pathways to primary visual cortex. Nature 426:668-671. CrossRef Medline

Chen S, Li W (2012) A color-coding amacrine cell may provide a blue-off signal in a mammalian retina. Nat Neurosci 15:954-956. CrossRef Medline

Chichilnisky EJ, Baylor DA (1999) Receptive-field microstructure of blueyellow ganglion cells in primate retina. Nat Neurosci 2:889-893. CrossRef Medline

Cleland BG, Levick WR (1974) Properties of rarely encountered types of ganglion cells in the cat's retina and an overall classification. J Physiol 240:457-492. Medline

Cleland BG, Levick WR, Morstyn R, Wagner HG (1976) Lateral geniculate relay of slowly conducting retinal afferents to cat visual cortex. J Physiol 255:299-320. Medline

Cohen E, Sterling P (1990a) Demonstration of cell types among cone bipolar neurons of cat retina. Philos Trans R Soc Lond B Biol Sci 330:305-321. CrossRef Medline

Cohen E, Sterling P (1990b) Convergence and divergence of cones onto bipolar cells in the central area of cat retina. Philos Trans R Soc Lond B Biol Sci 330:323-328. CrossRef Medline

Croner LJ, Kaplan E (1995) Receptive fields of P and M ganglion cells across the primate retina. Vision Res 35:7-24. CrossRef Medline

Crook JD, Davenport CM, Peterson BB, Packer OS, Detwiler PB, Dacey DM (2009) Parallel ON and OFF cone bipolar inputs establish spatially coextensive receptive field structure of blue-yellow ganglion cells in primate retina. J Neurosci 29:8372-8387. CrossRef Medline

Dacey DM (1993) Morphology of a small-field bistratified ganglion cell type in the macaque and human retina. Vis Neurosci 10:1081-1098. CrossRef Medline

Dacey DM, Lee BB (1994) The "blue-on" opponent pathway in primate retina originates from a distinct bistratified ganglion cell type. Nature 367:731-735. CrossRef Medline

Daw NW, Pearlman AL (1970) Cat colour vision: evidence for more than one cone process. J Physiol 211:125-137. Medline

de Monasterio FM (1979) Asymmetry of on- and off-pathways of bluesensitive cones of the retina of macaques. Brain Res 166:39-48. CrossRef Medline

Duong T, Freeman RD (2008) Contrast sensitivity is enhanced by expansive nonlinear processing in the lateral geniculate nucleus. J Neurophysiol 99:367-372. Medline

Ekesten B, Gouras P (2005) Cone and rod inputs to murine retinal ganglion cells: evidence of cone opsin specific channels. Vis Neurosci 22:893-903. Medline

Enroth-Cugell C, Freeman AW (1987) The receptive-field spatial structure of cat retinal Y cells. J Physiol 384:49-79. Medline

Enroth-Cugell C, Robson JG (1966) The contrast sensitivity of retinal ganglion cells of the cat. J Physiol 187:517-552. Medline

Enroth-Cugell C, Robson JG, Schweitzer-Tong DE, Watson AB (1983) Spatio-temporal interactions in cat retinal ganglion cells showing linear spatial summation. J Physiol 341:279-307. Medline

Famiglietti EV (2008) Wide-field cone bipolar cells and the blue-ON pathway to color-coded ganglion cells in rabbit retina. Vis Neurosci 25:53-66. Medline

Field GD, Sher A, Gauthier JL, Greschner M, Shlens J, Litke AM, Chichilnisky EJ (2007) Spatial properties and functional organization of small bistratified ganglion cells in primate retina. J Neurosci 27:13261-13272. CrossRef Medline

Fukuda Y, Stone J (1975) Direct identification of the cell bodies of Y-, Xand W-cells in the cat's retina. Vision Res 15:1034-1036. CrossRef Medline

Guenther E, Zrenner E (1993) The spectral sensitivity of dark- and lightadapted cat retinal ganglion cells. J Neurosci 13:1543-1550. Medline

Haverkamp S, Wässle H, Duebel J, Kuner T, Augustine GJ, Feng G, Euler T (2005) The primordial, blue-cone color system of the mouse retina. J Neurosci 25:5438-5445. CrossRef Medline

Hemmi JM, James A, Taylor WR (2002) Color opponent retinal ganglion cells in the tammar wallaby retina. J Vis 2:608-617. Medline

Jacobs GH (1993) The distribution and nature of colour vision among the mammals. Biol Rev Camb Philos Soc 68:413-471. CrossRef Medline

Jacobs GH, Fenwick JA, Williams GA (2001) Cone-based vision of rats for ultraviolet and visible lights. J Exp Biol 204:2439-2446. Medline

Johnson EN, Hawken MJ, Shapley R (2008) The orientation selectivity of color-responsive neurons in macaque V1. J Neurosci 28:8096-8106. CrossRef Medline

Johnson EN, Van Hooser SD, Fitzpatrick D (2010) The representation of S-cone signals in primary visual cortex. J Neurosci 30:10337-10350. CrossRef Medline

Kouyama N, Marshak DW (1992) Bipolar cells specific for blue cones in the macaque retina. J Neurosci 12:1233-1252. Medline

Krüger J (1977) Stimulus dependent colour specificity of monkey lateral geniculate neurones. Exp Brain Res 30:297-311. Medline

Krüger JK (1979) Responses to wavelength contrast in the afferent visual systems of the cat and the rhesus-monkey. Vision Res 19:1351-1358. CrossRef Medline

Lamb TD (1995) Photoreceptor spectral sensitivities: common shape in the long-wavelength region. Vision Res 35:3083-3091. CrossRef Medline

Lee BB, Pokorny J, Smith VC, Martin PR, Valberg A (1990) Luminance and chromatic modulation sensitivity of macaque ganglion cells and human observers. J Opt Soc Am A 7:2223-2236. CrossRef Medline

Lee BB, Silveira LC, Yamada ES, Hunt DM, Kremers J, Martin PR, Troy JB, da Silva-Filho M (2000) Visual responses of ganglion cells of a New-World primate, the capuchin monkey, Cebus apella. J Physiol 528:573-590. CrossRef Medline

Lee SC, Telkes I, Grünert U (2005) S-cones do not contribute to the OFFmidget pathway in the retina of the marmoset, Callithrix jacchus. Eur J Neurosci 22:437-447. CrossRef Medline

Li W, DeVries SH (2006) Bipolar cell pathways for color and luminance vision in a dichromatic mammalian retina. Nat Neurosci 9:669-675. CrossRef Medline

Linberg KA, Lewis GP, Shaaw C, Rex TS, Fisher SK (2001) Distribution of Sand $\mathrm{M}$-cones in normal and experimentally detached cat retina. J Comp Neurol 430:343-356. CrossRef Medline 
Livingstone MS, Hubel DH (1984) Anatomy and physiology of a color system in the primate visual cortex. J Neurosci 4:309-356. Medline

Loop MS, Bruce LL (1978) Cat color vision: the effect of stimulus size. Science 199:1221-1222. CrossRef Medline

Loop MS, Bruce LL, Petuchowski S (1979) Cat color vision: the effect of stimulus size, shape and viewing distance. Vision Res 19:507-513. CrossRef Medline

Loop MS, Millican CL, Thomas SR (1987) Photopic spectral sensitivity of the cat. J Physiol 382:537-553. Medline

Malpeli JG, Schiller PH (1978) Lack of blue OFF-center cells in the visual system of the monkey. Brain Res 141:385-389. CrossRef Medline

Mariani AP (1984) Bipolar cells in monkey retina selective for the cones likely to be blue-sensitive. Nature 308:184-186. CrossRef Medline

Martin PR, Blessing EM, Buzás P, Szmajda BA, Forte JD (2011) Transmission of colour and acuity signals by parvocellular cells in marmoset monkeys. J Physiol 589:2795-2812. CrossRef Medline

Michael CR (1966) Receptive fields of opponent color units in the optic nerve of the ground squirrel. Science 152:1095-1097. CrossRef Medline

Michail CR (1973) Opponent-color and opponent-contrast cells in lateral geniculate nucleus of the ground squirrel. J Neurophysiol 36:536-550. Medline

Mollon JD (1989) “Tho' she kneel'd in that place where they grew.” The uses and origins of primate colour vision. J Exp Biol 146:21-38. Medline

Mollon JD, Bowmaker JK, Jacobs GH (1984) Variations of colour vision in a New World primate can be explained by polymorphism of retinal photopigments. Proc R Soc Lond B Biol Sci 222:373-399. CrossRef Medline

Naka KI, Rushton WA (1966) S-potentials from luminosity units in the retina of fish (Cyprinidae). J Physiol 185:587-599. Medline

Nathans J (1999) The evolution and physiology of human color vision: insights from molecular genetic studies of visual pigments. Neuron 24:299312. CrossRef Medline

Pearlman AL, Daw NW (1970) Opponent color cells in the cat lateral geniculate nucleus. Science 167:84-86. CrossRef Medline

Polyanskii VB, Evtikhin DV, Sokolov EN (2006) Computation of color and brightness differences by rabbit visual cortex neurons. Neurosci Behav Physiol 36:235-245. CrossRef Medline

Puller C, Ondreka K, Haverkamp S (2011) Bipolar cells of the ground squirrel retina. J Comp Neurol 519:759-774. CrossRef Medline

Reid RC, Shapley RM (2002) Space and time maps of cone photoreceptor signals in macaque lateral geniculate nucleus. J Neurosci 22:6158-6175. Medline

Rodieck RW (1965) Quantitative analysis of cat retinal ganglion cell response to visual stimuli. Vision Res 5:583-601. CrossRef Medline

Rowe MH, Cox JF (1993) Spatial receptive-field structure of cat retinal W cells. Vis Neurosci 10:765-779. CrossRef Medline

Roy S, Jayakumar J, Martin PR, Dreher B, Saalmann YB, Hu D, Vidyasagar TR (2009) Segregation of short-wavelength-sensitive (S) cone signals in the macaque dorsal lateral geniculate nucleus. Eur J Neurosci 30:1517-1526. CrossRef Medline

Sher A, DeVries SH (2012) A non-canonical pathway for mammalian bluegreen color vision. Nat Neurosci 15:952-953. CrossRef Medline

Solomon SG (2002) Striate cortex in dichromatic and trichromatic marmosets: neurochemical compartmentalization and geniculate input. J Comp Neurol 450:366-381. CrossRef Medline

Solomon SG, Lee BB, White AJ, Rüttiger L, Martin PR (2005) Chromatic organization of ganglion cell receptive fields in the peripheral retina. J Neurosci 25:4527-4539. CrossRef Medline

Stone J, Hoffmann KP (1972) Very slow-conducting ganglion cells in the cat's retina: a major, new functional type? Brain Res 43:610-616. CrossRef Medline

Sur M, Sherman SM (1982) Linear and nonlinear W-cells in C-laminae of the cat's lateral geniculate nucleus. J Neurophysiol 47:869-884. Medline

Szél A, Lukáts A, Fekete T, Szepessy Z, Röhlich P (2000) Photoreceptor distribution in the retinas of subprimate mammals. J Opt Soc Am A Opt Image Sci Vis 17:568-579. CrossRef Medline

Szmajda BA, Buzás P, Fitzgibbon T, Martin PR (2006) Geniculocortical relay of blue-off signals in the primate visual system. Proc Natl Acad Sci U S A 103:19512-19517. CrossRef Medline

Tailby C, Solomon SG, Lennie P (2008a) Functional asymmetries in visual pathways carrying S-cone signals in macaque. J Neurosci 28:4078-4087. CrossRef Medline

Tailby C, Szmajda BA, Buzás P, Lee BB, Martin PR (2008b) Transmission of blue $(\mathrm{S})$ cone signals through the primate lateral geniculate nucleus. J Physiol 586:5947-5967. CrossRef Medline

Telkes I, Lee SC, Jusuf PR, Grünert U (2008) The midget-parvocellular pathway of marmoset retina: a quantitative light microscopic study. J Comp Neurol 510:539-549. CrossRef Medline

Troy JB (1983) Spatial contrast sensitivities of X and Y type neurones in the cat's dorsal lateral geniculate nucleus. J Physiol 344:399-417. Medline

Valberg A, Lee BB, Tigwell DA (1986) Neurones with strong inhibitory S-cone inputs in the macaque lateral geniculate nucleus. Vision Res 26 : 1061-1064. CrossRef Medline

van Arsdel RE, Loop MS (2004) Color vision sensitivity in normally dichromatic species and humans. Vis Neurosci 21:685-692. Medline

Vaney DI, Levick WR, Thibos LN (1981) Rabbit retinal ganglion cells. Receptive field classification and axonal conduction properties. Exp Brain Res 44:27-33. Medline

Van Hooser SD, Nelson SB (2006) The squirrel as a rodent model of the human visual system. Vis Neurosci 23:765-778. Medline

White AJ, Wilder HD, Goodchild AK, Sefton AJ, Martin PR (1998) Segregation of receptive field properties in the lateral geniculate nucleus of a New-World monkey, the marmoset Callithrix jacchus. J Neurophysiol 80:2063-2076. Medline

Wiesel TN, Hubel DH (1966) Spatial and chromatic interactions in the lateral geniculate body of the rhesus monkey. J Neurophysiol 29:1115-1156. Medline

Wilson PD, Rowe MH, Stone J (1976) Properties of relay cells in cat's lateral geniculate nucleus: a comparison of W-cells with X-and Y-cells. J Neurophysiol 39:1193-1209. Medline

Yeh T, Lee BB, Kremers J (1995a) Temporal response of ganglion cells of the macaque retina to cone-specific modulation. J Opt Soc Am A Opt Image Sci Vis 12:456-464. CrossRef Medline

Yeh T, Lee BB, Kremers J, Cowing JA, Hunt DM, Martin PR, Troy JB (1995b) Visual responses in the lateral geniculate nucleus of dichromatic and trichromatic marmosets (Callithrix jacchus). J Neurosci 15:7892-7904. Medline

Yin L, Smith RG, Sterling P, Brainard DH (2009) Physiology and morphology of color-opponent ganglion cells in a retina expressing a dual gradient of S and M opsins. J Neurosci 29:2706-2724. CrossRef Medline

Yokoyama S, Radlwimmer FB (1999) The molecular genetics of red and green color vision in mammals. Genetics 153:919-932. Medline 